\title{
Józef Kargul
}

Dolnośląska Szkoła Wyższa

\section{Powojenny ogląd samokształcenia w Polsce}

\author{
The post-war overview on self-education
}

Streszczenie. W artykule dokonano krytycznego przeglądu stanowisk dotyczących samokształcenia w Polsce w okresie powojennym. W konkluzji Autor stawia hipotezę o istnieniu dwóch typów osób uprawiających samokształcenie. Jeden z nich to ludzie, którzy podejmują trud samokształceniowy w celu upodobnienia się do określonego wzoru - są tzw. „zewnątrzsterownymi", i ludzie, podejmujący doskonalenie siebie (we wszystkich stronach własnej osobowości), aby sprawnie wykonywać zadania, które stawia przed nimi życie („wewnątrzsterowni").

Słowa kluczowe: andragogika, samokształcenie, edukacja nieformalna.

Summary. The paper presents a critical review of the positions on self-education in Poland after World War II. In conclusion, the author hypothesizes that there exist two types of people engaged in self-education. One type is applied to those who commit themselves to self-education in order to become similar to specific pattern and those people are referred to as "other-directed"; another one refers to people taking self improvement (in all sides of their own personality) to efficiently perform tasks that life puts in front of them (inner-directed).

Keywords: andragogy, self-education, non-formal education.

Chyba nikt nie ma wątpliwości, że konstruując własną karierę życiową, rozumianą jako świadome realizowanie wizji poszczególnych etapów własnego życia, korzystamy z wiedzy przekazywanej nam w formalnych instytucjach edukacyjnych, ale również wykorzystujemy wiedzę i informacje zdobywane ze źródeł niesformalizowanych, incydentalnie. Bardzo często bywa, że świadomie uruchamiamy wysiłek umysłowy, aby zdobyć określoną wiedzę, sami 
poszukujemy jej źródeł, stosujemy własne sposoby jej zdobywania, sami określamy jej przydatność dla realizacji określonych celów. Taki proces konstruowania przez siebie poszczególnych zamierzeń i realizowanie ich przez samodzielnie zaplanowane czynności edukacyjne określam pojęciem samokształcenia lub autoedukacji.

Niemal wszyscy współcześni polscy autorzy, pisząc o samokształceniu jako o edukacyjnym procesie kreowania siebie przez człowieka dorosłego, odwołują się do prac, które ukazały się w okresie międzywojennym. Nic dziwnego, bowiem po odzyskaniu niepodległości - co z perspektywy historycznej zasługuje na uznanie - intelektualiści, działacze polityczni, działacze oświatowi, przywódcy narodu zgodnie - niezależnie od przekonań politycznych i przynależności partyjnej - podjęli trud realizowania idei upowszechniania oświaty i kultury wśród niższych klas społecznych, aby w jak najkrótszym czasie zlikwidować zapóźnienie oświatowe i kulturalne pozostałe po rządach zaborców. Zatem było to poważne wyzwanie polityczne i znalazło wyraz $\mathrm{w}$ pociągnięciach praktycznych w dziedzinie oświaty dorosłych. Jednym z nich było przymusowe nauczanie na poziomie trzech klas szkoły powszechnej żołnierzy analfabetów, drugim - budowa sieci szkolnej, a trzecim - propagowanie idei samokształcenia i uruchamianie poradni samokształceniowych jako praktyk pełniących funkcje zastępcze w stosunku do niewydolnej jeszcze sieci szkół.

Te polityczne pociągnięcia dotyczące praktyk w zakresie oświaty dorosłych zainspirowały badaczy tej problematyki do refleksji nad procesem samokształcenia; powstały w tym czasie dwa znaczące opracowania na temat aktywności samokształceniowej autorstwa Władysława Spasowskiego (Zasady samokształcenia, 1923, III wydanie 1961) i Władysława Okińskiego (Procesy samokształceniowe, 1935). Samokształcenie w ujęciu pierwszego autora polega „na samodzielnym stawianiu i rozwiązywaniu zadań koniecznych, bo wypływających z odczuwanej natury i uświadamianych potrzeb coraz intensywniejszego i pełniejszego życia osobnika" (s. 34-35). Natomiast definicja Okińskiego (bardzo podobna do wcześniejszej definicji Floriana Znanieckiego opublikowanej w artykule w języku angielskim: Znaniecki, 1928, s. 127) odmiennie ujmuje istotę samokształcenia. Wedle niego „proces samokształceniowy (albo krócej: samokształcenie) to tyle co samodzielne, poddane autokontroli urabianie się osobnika w celu osiągnięcia jakiegoś mniej lub więcej uchwytnego (uświadamianego) i mniej lub więcej jasno określonego wzoru (ideału) osobowości” (s. 34). Warto również w tym miejscu odnotować bardzo interesujące zdanie działającego w okresie międzywo- 
jennym pedagoga kultury Sergiusza Hessena, który o samokształceniu pisał metaforycznie w ten sposób:

Jest to podróż w kraju ducha, w świecie kultury ludzkiej, a doniosłym i głębokim zdarzeniem w tej wędrówce ducha ludzkiego może stać się przelotna rozmowa, przypadkowe spotkanie, przeczytana książka, wysłuchany koncert lub wykład, przestawienie teatralne [...]. Dlatego jest rzeczą niemożliwą podanie jakiejś całkowitej teorii środków samokształcenia. Zatrzymać się jednak należy dokładniej przy niektórych, jako że rozwinęły się w naszych czasach w szerokie samodzielne instytucje. Takimi środkami są dzisiaj szczególnie biblioteki, muzea, wyższe zakłady naukowe, czasopisma, wystawy, odczyty i referaty w towarzystwach naukowych i zawodowych (s. 174).

Studiując tę problematykę, nawiązanie do takiego ujęcia samokształcenia odnalazłem jedynie u psychologa Stefana Baleya, natomiast podobne myślenie o samokształceniu nie miało miejsca wśród późniejszych badaczy.

Po zakończeniu drugiej wojny światowej państwo polskie miało nie tylko zrujnowany kraj i narzucony ustrój polityczny, ale i kilka milionów analfabetów (dokładnej liczby nikt nie zna, jedynie znane są dane szacunkowe. Najczęściej podawane są liczby 3,5-4 milionów, ale spotkałem i wyższe 5 milionów). Władze państwa podjęły - wraz z decyzją odbudowy materialnej zniszczonego kraju - ważną decyzję polityczną dotyczącą likwidacji analfabetyzmu. Pociągnięcia praktyczne w tym zakresie polegały między innymi na tym, że kursy dla analfabetów miały prowadzić nie tylko szkoły, ale takie instytucje kultury i oświaty, jak np. odradzające się domy społeczne, domy kultury i świetlice. W trzy lata później, w roku 1952 ogłoszono publicznie, że analfabetyzm w Polsce został zlikwidowany. Na dowód tego podawano liczby zrealizowanych kursów dla analfabetów, liczby ich uczestników (różne były statystyki: od 1,2 miliona do 1,5 miliona). Wszyscy jednak, zarówno politycy, jak i działacze oświatowi oraz badacze, mieli świadomość, że opanowanie umiejętności czytania i pisania na poziomie elementarnym nie jest wystarczające, aby w pełni uczestniczyć w życiu społeczno-politycznym, a przede wszystkim, aby być „świadomym obywatelem budującym ustrój socjalistycznej ojczyzny”, o co chodziło władzom partii komunistycznej i państwa. Podjęto więc decyzję, aby propagować samokształcenie jako drogę zdobywania wiedzy i doskonalenia nabytych umiejętności (w szkole lub na kursach). W dzieło propagowania samokształcenia włączyli się powojenni badacze oświaty dorosłych (tak w PRL określano ten obszar działalności społecznej), starając się nieco głębiej analizować samo zjawisko tego procesu i formułować dyrektywy prakseologiczne jego uprawiania. 
Śledząc publikacje na temat samokształcenia ukazujące się w PRL, można zauważyć osobliwe zjawisko, że cytowane wyżej określenia Okińskiego i Spasowskiego podzieliły środowisko andragogów i pedagogów zajmujących się samokształceniem w latach późniejszych.

Andragodzy w zdecydowanej większości przyjmowali i przyjmują określenie Okińskiego eksponujące dążenie samouka do realizacji określonego wzoru osobowego (ideału?). Aprobująco powoływali się i powołują na to określenie między innymi: Tadeusz Aleksander, Czesław Maziarz, Józef Półturzycki, Kazimierz Wojciechowski, Franciszek Urbańczyk; nie odżegnywał się od takiego ujęcia również Dzierżymir Jankowski. Szerzej na ten temat wypowiedział się Jerzy Semków, który realizację przyjętego wzoru osobowego przez samouka uznawał jako jego podstawowe zadanie w procesie samokształceniowym. Pisał bowiem:

W przyjętym przez nas rozumieniu celem samokształcenia jest osiągnięcie, funkcjonującego na różnych pokładach świadomości ludzkiej, wzoru osobowości. Konsekwentnie zatem zakładamy, że świadomość - choćby niepełna celu podejmowanej przez jednostkę działalności zadaniowej - jest warunkiem koniecznym samokształcenia. Podobnie widzą to inni autorzy. Uznany w prezentowanym tutaj rozumieniu za cel samokształcenia wzór osobowy, może być wyobrażeniem bądź w miarę pełnego zbioru cech jednostkowych, bądź tylko jego częścią (Semków, 1987, s. 104).

Z kolei psychologowie, pedagodzy i niektórzy andragodzy aprobowali te określenia samokształcenia, które eksponują dążenie do realizacji zróżnicowanych celów i zadań postawionych sobie przez samouka (które mogą się zmieniać). Takie zdanie wyrażali Mieczysław Malewski, Józef Pieter, Wincenty Okoń, Czesław Kupisiewicz, Ryszard Wroczyński, Józef Kargul. Na przykład Wincenty Okoń traktował samokształcenie jako „osiąganie wykształcenia poprzez działalność, której treść, cele warunki i środki ustala sam podmiot. W procesie samokształcenia jego cele dynamizują się, osiągnąwszy wyższy stopień świadomości uczeń dokonuje często ich przewartościowania i doskonalenia. Samokształcenie osiąga optymalny poziom wtedy, gdy przekształca się w stałą potrzebę życiową człowieka oraz stanowi oparcie dla kształcenia ustawicznego" (1981, s. 269).

Można oczywiście dyskutować, czy i na ile samokształcący się dorosły, żyjąc w kulturze kolektywizmu w PRL, miał szansę zdobywać taką wiedzę czy wiedzę z takich zakresów, które tylko on sam uznałby za godne zainteresowania, i na ile uprawiał samokształcenie bez ingerencji funkcjonariuszy 
państwa socjalistycznego. Trzeba bowiem odnotować, że zezwolenie na ten rodzaj aktywności, będące dowodem, iż tendencja przedmiotowego postrzegania ucznia dorosłego nie jest jedyna, było bardzo ograniczone. Bardzo szybko bowiem poradzono sobie $\mathrm{z}$ indywidualizmem $\mathrm{w}$ samokształceniu, wymyślając „samokształcenie kierowane”. A oto pogląd jednego z badaczy na temat owego „samokształcenia kierowanego”, który pisał m.in.:

Samokształcenie jest - jak sama nazwa wskazuje - działaniem osobistym, jednakże błędem byłoby mniemać, że polega ono po prostu na wysiłku danej osoby, na polu zdobywania wiedzy i urabiania własnego charakteru. Samokształcenie skuteczne jest społeczną akcją wychowawczą, a więc akcją dobrze zaplanowaną, zorganizowaną i urzeczywistnianą. Akcent na samodzielność wskazuje tylko na większy niż w wychowaniu dzieci rozmiar samooceny i samosterowania, na relatywnie większy rozmiar samowiedzy. Każe się domyślać innych metod, aniżeli w wypadku wychowania dzieci. Wśród metod świadomej współpracy między kierownikami akcji samokształcenia a osobami biorącymi w niej udział (Pieter, 1963, s. 346-347).

Jak widać, można i tak było pojmować samokształcenie. Tylko zachodzi pytanie, czy w tym przypadku można mówić w ogóle o samokształceniu. Niezależnie od mojego mniemania na ten temat - paradoksalnie - termin „samokształcenie kierowane" obecnie funkcjonuje i jest powszechnie używany nie tylko przez organizatorów rozmaitych kursów i tak zwanych szkoleń, którzy zadając dorosłym określone zadania do wykonania, wmawiają słuchaczom, że będzie to samokształcenie, ale i przez niektórych andragogów.

Pisząc o samokształceniu, trzeba odnotować oryginalną, nowatorską zupełnie odmienną, analizę samokształcenia od ujęć cytowanych tu autorów, jaką zaprezentowała Zofia Matulka (1979) w pracy zatytułowanej Selekcja i synteza informacji w procesie samokształcenia. Autorka wyszła z założenia, że

istotą samokształcenia jest gromadzenie i przechowywanie informacji potrzebnych do rozwiązania podstawowych problemów, opracowania zaplanowanych tematów, nabycia pożądanych sprawności. [...] Mamy dwa źródła informacji: rzeczywistość przekazującą informacje o sobie oraz komunikaty nadawane przez człowieka, przekazujące informacje o rzeczywistości pośrednio. Umiejętność obserwacji rzeczywistości, badania jej [...], rozumienia i gromadzenia na tej podstawie informacji o niej, ujmowanie tych informacji w formie językowej, obrazowej i symbolicznej jest w procesie samokształcenia niezbędna (s. 52). 
Autorka stworzyła więc i opisała teoretyczny model procesu samokształcenia, w którym pokazała, iż można łatwo uporządkować i scalić wszystkie działania wchodzące w skład procesu, jeśli się go potraktuje jako proces komunikacji i przetwarzania informacji (s. 277). W drodze badań eksperymentalnych starała się odpowiedzieć, jak są przygotowani do samokształcenia, czyli do selekcji i syntezy informacji, maturzyści i studiujący nauczyciele. W konsekwencji następująco zdefiniowała termin „samokształcenie”, pisząc, „że jest to proces, tzn. ciąg logicznie ze sobą ściśle zorganizowanych czynności osoby uczącej się, mający na celu samodzielne, bez bezpośredniego kierownictwa nauczyciela, przyswojenie sobie pożądanych informacji, umiejętności operowania tymi informacjami, sprawności intelektualnych i manualnych oraz wyćwiczenie zdolności poznawczych: spostrzegania, uwagi, wyobraźni, pamięci i krytycznego myślenia" (s. 62). Autorka wyraźnie odróżnia samokształcenie postrzegane przez nią jako działania autokreacyjne, które dotyczą intelektualnego rozwoju człowieka, obejmujące sferę poznawczą, od samowychowania, którym jest samodzielne wyrabianie poglądów, przekonań i postaw, dodając na marginesie, że być może te dwa procesy się przenikają i uprawiający je pragną się upodobnić do jakichś ideałów czy wzorów osobowych, ale o wzorach i ideałach przy analizie samokształcenia mówić nie zamierza.

O ile mi wiadomo, to pionierskie dzieło wyraźnie odbiegające od pedagogiczno-andragogicznych ujęć nie znalazło entuzjastów, a środowisko andragogów w tej kwestii jest nadal podzielone. W dalszym ciągu jedni sądzą, że samouk pragnie się upodobnić do jakiegoś wzoru i budując własną karierę, podejmuje trud samokształceniowy - a inni są przekonani, że to konieczność rozwiązywania zadań życiowych, jakie stoją przed człowiekiem, zmusza go do samokształcenia.

Świadczą o tym późniejsze prace na ten temat. Otóż cytowany już Semków podtrzymuje swoje stanowisko sprzed przeszło ćwierćwiecza. W opublikowanym artykule w roku 2013 pisze m.in.

Wydaje się bowiem, iż działania samodzielnie uczącego się człowieka nie mogą odwoływać się wyłącznie do jego chęci bycia lepiej zorientowanym, lepszym w jakieś dziedzinie, generalnie bardziej rozumiejącym otaczający go świat, gdyż potencjał tego rodzaju motywacji może okazać się za słaby. Stąd potrzeba zaistnienia wzoru osobowego, to jest osobowości na tyle znaczącej, emanującej swoimi umiejętnościami bądź silnie zaznaczonymi cechami, która byłaby punktem odniesienia dla jednostki podejmującej samodzielne uczenie się (Semków, 2013, s. 83). 
Jako argument autor przytacza wypowiedzi uczestników programów telewizyjnych typu Idol, Mam talent czy Szansa na sukces, pisząc m.in.: „W poprzedzających występ w telewizji wywiadach artyści amatorzy pytani o osoby, które były dla nich wzorem, często podawali konkretne, znane postacie reprezentujące nie tylko świat sztuki, których osiągnięcia mobilizowały uczestników owych telewizyjnych programów do wzmożonej pracy nad sobą" (Semków, 2013, s. 83-84)1.

Z kolei przedstawiciele młodego pokolenia badaczy odmiennie niż Semków ujmują sedno samokształcenia. Na przykład Joanna Jarmużek pisze m.in.

Specyfika tej formy uczenia się polega na tym, iż jest ona splotem dwóch wysoce rozwiniętych cech uczenia się: świadomości (własnych możliwości i aspiracji) i samodzielnej aktywności - sprawiają one, że samokształcenie dokonuje się na drodze, na której jednostka uczy się sama dzięki określaniu i wytyczaniu sobie kolejnych zadań edukacyjnych. Aktywna postawa wobec uczenia się zakłada internalizację edukacji jako wartości oraz dysponowanie strategiami pozwalającymi na samodzielne wyznaczanie dróg kształcenia i własnego rozwoju. W tej sytuacji uczenie się jawi się jako aktywność, którą podmiot sam organizuje i steruje według własnych możliwości, doświadczeń i celów (2006, s. 1).

Przyznam, że takie rozumienie samokształcenia jest mi bardzo bliskie, bowiem jest zbieżne z tym, co pisałem na początku tego tekstu. Nadto podzielam pogląd autorki piszącej, że najistotniejszym warunkiem samokształcenia jest umiejętność precyzowania celów, zakresu wiedzy do opanowania, przekładania celów ogólnych na zadania szczegółowe, umiejętności planowania pracy samokształceniowej oraz gotowość do jej podjęcia, którą uzyskuje się dzięki wcześniejszemu kształceniu kierowanemu (Jarmużek, 2006).

Z kolei Ewelina Basińska, w metaforycznie zatytułowanej pracy Tuning życia - sekrety ksztatcenia $w$ ujęciu andragogicznym (2014) też nie eksponuje roli wzoru osobowego pisząc, że „samokształcenie to wszelkie działania, które podejmuje człowiek w celu podnoszenia swojego wykształcenia, kwalifikacji zawodowych, a także pośrednio swojej samooceny i własnej wartości” (s. 29). Jednocześnie trafnie zauważa, że „samokształcenie rozumiane jako indywidualnie obierana przez uczącego się droga podnoszenia kwalifi-

1 W tym miejscu nasuwa się refleksja, że argument jakoby wzór osobowy był „motorem" samokształcenia, ponieważ pytani w wywiadach wskazywali osoby, na których się wzorowali, dla mnie jest nieprzekonujący ze względu na konstrukcję werbalną zadanego pytania, sugerującą, że taki wzór odpowiadający powinien mieć. 
kacji - nie jest procesem jednakowym dla wszystkich". Aby wytrwać w dążeniach samokształceniowych zdaniem autorki trzeba „stawiać sobie ciągle nowe pytania, uruchamiać akt woli, rzeczywiście się wysilać, pobudzać obie półkule mózgowe, zmieniać dotychczasowe przyzwyczajenia i czerpać radość z najmniejszego nowego doświadczenia" (s. 32).

Analizując ujęcia, określenia, definiowanie samokształcenia nie sposób pominąć poglądów Józefa Półturzyckiego, autora wielu wypowiedzi na temat. W ostatnio wydanej książce pt. Niepokój o dydaktykę (2014) samokształceniu poświęcił jeden rozdział, powtarzając sformułowaną kilkanaście lat temu własną jego definicję. Autor pisze:

Samokształcenie jest bowiem zarówno procesem oświatowym, jak i stylem życia, związanym z aktywnym poznawaniem świata i samego siebie, doskonalenia swej osobowości we wszystkich dziedzinach kształcenia i wychowania, nie tylko umysłowej, ale także społeczno-moralnej, estetycznej, i fizyczno-zdrowotnej. Głównym czynnikiem i warunkiem samokształcenia jest aktywność edukacyjna wynikająca z samodzielności planowania i podejmowania działań edukacyjnych dla siebie i środowiska społecznego we wszystkich sferach życia i kultury. Samokształcenie nie jest procesem wyizolowanym, który można dodać do systemu edukacji szkolnej czy oświaty dorosłych, natomiast jest mniej lub bardziej świadomym działaniem edukacyjnym, które się łączy ze zorganizowanym kształceniem i wychowaniem, z rezultatami społecznych wzajemnych oddziaływań i z samorzutnym rozwojem każdego człowieka (Półturzycki, 2014, s. 432).

Nie będę ukrywał, że w moim przekonaniu takie określenie samokształcenia budzi zastrzeżenia. Po pierwsze autor proponując definicję równościową, w definiensie umieszcza dwa wyrażenia - proces i styl życia, będące zupełnie różnymi kategoriami pojęciowymi, i zakłada ich identyczność (gdyby napisał, że samokształcenie jest elementem stylu życia, to bym się zgodził). Po drugie, niezależnie od wskazanej tu niezręczności w samej definicji, jest ona za szeroka. Wczytując się bowiem literalnie i dokonując hermeneutycznej analizy tego tekstu, można dojść do wniosku, że wszelka aktywność edukacyjna człowieka dorosłego podejmowana zarówno wobec siebie, jak i otoczenia jest samokształceniem. A oto empiryczny przykład na to, jaki może być skutek przyjęcia tak szerokiej definicji. Otóż dwie autorki, bardzo dobrej skądinąd pracy dotyczącej uczenia się dorosłych, Alina Matlakiewicz i Hanna Solarczyk-Szwec - w drugim wydaniu swojej książki Dorośli uczq się inaczej, przyjąwszy cytowaną wyżej definicję samokształcenia zaproponowaną 
przez Półturzyckiego, będąc konsekwentnymi w logicznym rozumowaniu, napisały m.in.:

Proces samokształcenia rzadko występuje w postaci czystej, najczęściej jest uwikłany w inne procesy oświatowe, do których należy kształcenie programowe, wychowanie w środowisku i udział w różnych formach działalności pozaszkolnej. Uwzględniając różne zewnętrzne uwarunkowania można wyróżnić następujące rodzaje samokształcenia:

Samokształcenie wspomagane bądź kierowane: przyjmuje formę poradnictwa, konsultacji, niekiedy fragmentarycznego kierownictwa bezpośredniego (np. kształcenie korespondencyjne).

Samokształcenie kierowane pośrednio: występuje głównie ze strony autorów, twórców i redaktorów źródeł informacji z których korzystają osoby uprawiające samokształcenie; do źródeł tych należą podręczniki, przewodniki metodyczne, programy i pakiety multimedialne oraz różnego rodzaju materiały pomocnicze (np. rysunki, wykresy, tablice).

Samokształcenie samoistne/właściwe: osoby uczące się samodzielnie czerpią wiedzę ze źródeł naukowych, materiałów i komunikatów nie przeznaczonych do samokształcenia, a także bezpośrednio z obserwacji otaczającej rzeczywistości; wymaga to dużej dojrzałości intelektualnej, umiejętności wnikliwej obserwacji, właściwej interpretacji wyników, umiejętności systematyzowania i strukturyzowania uzyskanych danych.

Wszystkie wymienione procesy mogą występować w różnych kombinacjach i układach np.: mogą się wzajemnie zaburzać, mogą być komplementarne, poprzedzające, następcze (Matlakiewicz, Solarczyk-Szwec, 2009, s. 136).

W świetle tej wypowiedzi samokształceniem może być zarówno poradnictwo, jak i konsultacja, samodzielne korzystanie z polecanego poradni$\mathrm{ka}$ /przewodnika, jak i wykonywanie zadania zadanego przez nauczyciela w kształceniu korespondencyjnym, samodzielne wyszukiwanie określonego źródła wiedzy i wykorzystanie źródła wskazanego przez nauczyciela (edukatora).

Osobiście nie mogę jednak zaaprobować takiego szerokiego rozumienia i definiowania samokształcenia, bowiem znika z niego to, co dla mnie jest istotą, czy też - inaczej - ontologicznym statusem, a mianowicie samodzielność osoby podejmującej trud autoedukacji wyrażający się w doborze celu tego wysiłku oraz metod - sposobów zdobywania wiedzy i informacji, będących środkami realizacji owego celu. Te elementy samokształceniowego procesu, wprawdzie nie expressis verbis zawarłem w jego określeniu zaprezentowanym na wstępie tej wypowiedzi. Cytowane Autorki prawdopodobnie zauważyły ową „szerokość” określenia samokształcenia i zastosowały 
pewien zabieg interpretacyjny, żeby uniknąć zarzutu, iż do „jednego worka” wkładają wszystkie sposoby zdobywania wiedzy przez uczącego się dorosłego. Otóż jak widać w cytowanym fragmencie, wymieniły trzy rodzaje samokształcenia, a tylko jedno uznały jako „właściwe”.

Wprawdzie nie do końca mnie takie zabiegi przekonały, ale nasunęły taką myśl, że transformacja ustroju w Polsce, dynamiczne zmiany społeczno-kulturowe, jakie przeżywamy aktualnie w XXI wieku, być może wymagają innego spojrzenia, przyjęcia innej perspektywy analiz tego wszystkiego, co kryje się pod rozmaicie rozumianym terminem „samokształcenie”.

Po pierwsze nastąpiły gwałtowne zmiany społeczno-kulturowe spowodowane przyjęciem - może lepiej: wtargnięciem - w życie społeczno-polityczne naszego kraju neoliberalnych ideologii z dominującym dyskursem politycznym i ekonomicznym, przyjmującym, że „niewidzialna ręka rynku” jest jedyną siłą regulującą zarówno życie całego społeczeństwa, jak i indywidualnych osób. W myśl tych ideologii wszystko jest towarem - zarówno towar materialny, jak i myśl ludzka, projekt nowego samochodu i lansowana idea filozoficzna. To wszystko zbiegło się z faktem, że modernistyczna wizja świata zaczęła być nie tylko krytykowana, ale wręcz unieważniana przez myślicieli, badaczy, filozofów, przekonujących nas, iż nie jest tak, że świat społeczno-kulturowy jest światem pewnym, jednoznacznym, kierowanym przez utrwalone, niezmienne prawa lub prawidłowości, które można odkryć dzięki badaniom naukowym, jednoznacznie opisać i przewidzieć niemal ze stuprocentową pewnością bieg zdarzeń. Nadto współczesny człowiek poddawany naciskom wszechogarniającej reklamy nie tylko towarów i usług, ale - w ramach neoliberalizmu - idei i ideologii, opcji politycznych, aktywności społecznej, edukacyjnej i kulturalnej, ma szeroki wachlarz pozornego wyboru.

Po drugie zmiany zachodzące $w$ dziedzinie nauk społecznych i humanistycznych polegające na podważeniu wiarygodności badań prowadzonych $\mathrm{w}$ paradygmacie pozytywistycznym i post-pozytywistycznym spowodowały wzrost ostrożności w formułowaniu jednoznacznych dyrektyw prakseologicznych szczególnie w dziedzinie edukacji. Pociągnęło to za sobą zmianę nie tylko języka opisu zjawisk edukacyjnych, ale i zmianę postrzegania procesów nauczania i uczenia się. W pracach andragogów coraz rzadziej można spotkać termin „samokształcenie”, a coraz częściej „edukacja ustawiczna” i "całożyciowe uczenie się" jako terminy opisujące zarówno praktyki edukacyjne dorosłych, jak i postulaty badaczy propagujących owe praktyki. Postulaty te wyraźnie odsuwają władze państwa od odpowiedzialności za ofertę edukacyjną - tę reguluje rynek i za decyzję wyboru dotyczącą aktywności 
człowieka w tej przestrzeni tu odpowiedzialność spada na konkretną jednostkę.

Można nawet zaryzykować postawienie pytania, czy w świetle badań uczących się dorosłych, w tym również emigrantów, a szczególnie w świetle przybliżonych przez Mieczysława Malewskiego teorii uczenia się człowieka dorosłego, spór badaczy o rozumienie samokształcenia nie jest sporem jałowym o nieistniejące już zjawisko. Przede wszystkim wspomniane badania pokazują, że współczesnym człowiekiem podejmującym trud edukacyjny kierują motywy rozmaitej natury - to po pierwsze, a po drugie - motywacja ta się zmienia w zależności do sytuacji życiowej, która jest nie zawsze pewna i stabilna. Edukacja jako element kreowania jego tożsamości musi być zmienna, bowiem zależy od wyboru owej tożsamości, którą też można wybrać z „szafy z tożsamościami” - jak to ujął w powszechnie znanym metaforycznym wyrażeniu Zygmunt Bauman. A jeżeli tak, to można hipotetycznie założyć, że jedna i ta sama osoba może podejmować trud samokształcenia zarówno dlatego, że w danej chwili uświadomiła sobie - pod wpływem zewnętrznych impulsów - iż musi zdobyć samodzielnie informacje, wiedzę i umiejętności, by móc rozwiązywać określone zadania stojące na jej drodze życia, postrzegane przez nią jako ważne z jakichś powodów, lub też, że w danej chwili dostrzegła szansę życiową w tym, iż dzięki aktywności edukacyjnej zbliży się do określonego wzoru osobowościowego, który jest właśnie nie tylko aprobowany, ale lansowany w mediach, w określonych kręgach, i/lub którym w danej chwili jest zafascynowana, ale za chwilę może go porzucić. Zastanawiam się tylko, czy to „upodobnianie się” oraz kształtowanie własnego charakteru i moralnej strony osobowości, by być podobnym do wybranego wzoru osobowego, nie jest subiektywnie postawionym „zadaniem", które trzeba rozwiązać.

Nadto okazuje się, że najnowsze badania nad uczeniem się człowieka dorosłego pokazują, że błędem byłoby zakładać, że wszyscy ludzie w jednakowym zakresie skłonni są uprawiać samokształcenie. Niektórzy badacze bardzo dużą wagę przywiązują do roli nauczyciela, bowiem - jak się okazuje - są dorośli uczący się, którym odpowiada nauczyciel-trener, wskazujący, co i jak uczący musi opanować, i pod jego kierownictwem takie osoby wykonują określone prace. W moim przekonaniu ci dorośli uczący się nie uprawiają samokształcenia, tylko wykonują zadania zlecone przez nauczyciela. Są również inni dorośli uczący się, którym nauczyciel podczas wykładu lub innych zajęć dydaktycznych daje impuls do stanowienia określonych celów, a nawet strategii uczenia są, które uczący się dorosły konstruuje i samodzielnie realizuje. 
Kończąc ten krótki przegląd poglądów na temat samokształcenia, jestem skłonny uznać, że być może są dwa typy osób uprawiających samokształcenie. Jeden z nich to ludzie, którzy podejmują trud samokształceniowy w celu upodobnienia się do określonego wzoru - psychologowie określiliby ich „zewnątrzsterownymi”, i są ludzie podejmujący doskonalenie siebie (we wszystkich stronach własnej osobowości), aby sprawnie wykonywać zadania, które stawia przed nimi życie („wewnątrzsterowni”).

Niezależnie jednak od tego jak człowiek będzie postrzegał istotę samokształcenia, w dzisiejszych czasach jest ono koniecznością, bowiem zmieniają się zarówno ideały, wzory osobowości, które można zinternalizować, jak również życie stawia nowe zadania, które musimy rozwiązywać.

Natomiast interesującym jest zagadnienie, jak dzisiaj osoby uprawiające samokształcenie określiłyby motywację do jego uprawniania. Czy w ogóle, a jeśli tak - to do jakich wzorów osobowych chciałyby się upodobnić? Do rozwiązywania jakiego rodzaju zadań można nabyć umiejętności w drodze samokształcenia, a jakiej kategorii zadania zawodowe, życiowe wymagają zdobywania wiedzy i umiejętności w toku formalnej edukacji? Co różnicuje motywację do samokształcenia osób je uprawiających? Odpowiedzi na te pytania można, owszem, znaleźć, jednak pod warunkiem przeprowadzenia pogłębionych badań empirycznych, które w celach poznawczych być może warto podjąć.

\section{Bibliografia}

Matlakiewicz A., Solarczyk-Szwec H. (2009), Dorośli uczą się inaczej. Andragogiczne podstawy kształcenia ustawicznego, Wydawnictwo Centrum Kształcenia Ustawicznego, Torun.

Matulka Z. (1979), Selekcja i synteza informacji w procesie samoksztatcenia, PWN, Warszawa.

Okiński W. (1935), Procesy samokształceniowe, Dom Książki Polskiej, Poznań.

Okoń W. (1981), Słownik pedagogiczny, PWN, Warszawa.

Pieter J. (1963), Psychologiczne problemy samokształcenia, Nasza Księgarnia, Warszawa.

Półturzycki J. (1991), Dydaktyka dorostych, Wydawnictw Szkolne i Pedagogiczne, Warszawa.

Półturzycki J. (2014), Niepokój o dydaktykę, Instytut Technologii Eksploatacji Państwowy Instytut Badawczy, Warszawa-Radom.

Semków J. (1987), Poznawanie świata i doskonalenie siebie wobec możliwości i ograniczeń środowiskowych; człowiek na drodze samoksztatcenia, [w:] Uczący się dorosty 
w świetle badań. Materiały konferencyjne 28-29 września 1987, Wydawnictwo Uniwersytetu Łódzkiego, Łódź.

Semków J. (2013), Całożyciowe uczenie się z perspektywy wielokulturowych problemów współczesności, [w:] Solarczyk-Ambrozik E. (red.), Całożyciowe uczenie się jako wyzwanie dla teorii i praktyki edukacyjnej, Wydawnictwo Naukowe UAM, Poznań.

Spasowski W. (1923, III wyd. 1961), Zasady samokształcenia, Książka i Wiedza, Warszawa.

Znaniecki F, Socjologia wychowania, t. II, Warszawa 1928.

\section{Netografia}

Basińska E. (2012), Tuning życia - sekrety kształcenia w ujęciu andragogicznym, Łódź, www.postawnarozwoj.uni.lodz.pl/admin/.../TUNING\%20ŻYCIA.pdf (dostęp: 05.06.2014).

Jarmużek J. (2014), Samokształcenie wymaga określenia własnej tożsamości, „Edukacja i Dialog", luty 2006, www.eid.edu.pl (dostęp: 05.06.2014). 
